\title{
IMPLEMENTASI KEBIJAKAN DIVERSIFIKASI KONSUMSI PANGAN LOKAL DI KABUPATEN PATI
}

\section{POLICY IMPLEMENTATION OF LOCAL FOOD CONSUMPTION DIVERSIFICATION IN PATI REGENCY}

\author{
Sri Utami \\ Dinas Ketahanan Pangan Kabupaten Pati \\ Email: Eltami135@yahoo.co.id
}

Naskah Masuk: 23 Juli 2018

Naskah Revisi: 1 Oktober 2018

Naskah Diterima: 12 Oktober 2018

\begin{abstract}
The pattern of community food consumption in Pati Regency has not been ideal yet in practice. The aims of this study are to find out the policy implementation of local food consumption diversification in Pati Regency, and to analyze the factors that influence the implementation of the policy. This research used qualitative method. The research was conducted in Pati regency, by conducting in-depth interviews to 18 (eighteen) informants from related agencies and targetted groups/communities. The data analyses include data reduction, data presentation and conclusion. The results of the research showed that the policy implementation of diversification of local food consumption in Pati Regency did not run well. There were 4 factors that impeded the policy implementation: (1) Communications, the delivery of policy content/socialization to policy implementers has not conducted well; (2) Resources, inadequate human resource in terms of quantity and quality. The agencies actively involved were only 7 (seven) of 11 (eleven) related agencies; (3) Organizational structure, the preparation of SOP was too late so it did not support effectively the implementation the policy; and (4) Communities attitudes towards local food, the communities considered that local food was "out of date and ndeso" and tended to like foods that were considered modern.
\end{abstract}

Keywords: consumption diversification, policy implementation, local food

\begin{abstract}
ABSTRAK
Pola konsumsi pangan masyarakat Kabupaten Pati belum ideal. Pemerintah Kabupaten Pati mengeluarkan Perda Nomor 28 Tahun 2010 tentang Kebijakan Percepatan Penganekaragaman Konsumsi Pangan Berbasis Sumber Daya Lokal. Penelitian ini bertujuan untuk mengetahui implementasi kebijakan diversifikasi konsumsi pangan lokal di Kabupaten Pati, dan melakukan analisis faktor-faktor yang mempengaruhi implementasi kebijakan tersebut. Penelitian ini menggunakan metode kualitatif. Penelitian dilakukan di Kabupaten Pati, dengan melakukan wawancara mendalam kepada 18 (delapan belas) informan yang berasal dari instansi yang melaksanakan kebijakan diversifikasi konsumsi pangan lokal, dan kelompok sasaran / masyarakat. Analisis data yaitu reduksi data, penyajian data dan penarikan kesimpulan. Hasil penelitian menunjukkan bahwa implementasi kebijakan diversifikasi konsumsi pangan lokal di Kabupaten Pati tidak berjalan dengan baik. Faktor-faktor yang menghambat implementasi kebijakan: (1) Komunikasi, penyampaian isi kebijakan/sosialisasi kepada para pelaksana kebijakan tidak dilakukan dengan baik; (2) Sumber daya, dukungan sumber daya manusia yang kurang baik dari segi jumlah maupun kualitasnya. Instansi yang terlibat hanya 7 (tujuh) dari 11 (sebelas) instansi pelaksana; (3) Struktur organisasi, penyusunan SOP terlambat sehingga tidak efektif mendukung pelaksanaan kebijakan; dan (4) Sikap masyarakat terhadap pangan lokal, masyarakat menganggap bahwa makanan lokal adalah makanan yang "kuno dan ndeso" dan lebih cenderung ke pangan lainnya seperti roti dan western food yang dianggap modern.
\end{abstract}

Kata kunci : diversifikasi konsumsi, implementasi kebijakan, pangan lokal 


\section{PENDAHULUAN}

Kabupaten Pati sebagai daerah yang peduli terhadap pembangunan pertanian mempunyai potensi produksi pangan lokal yang cukup tinggi. Selain produksi beras, Kabupaten Pati juga menghasilkan ubi kayu dan jagung. Produksi rata-rata ubi kayu per tahun sebesar 534.253 ton dan jagung rata-rata per tahun sebesar 100.778 ton (BPS Kab.Pati, 2016).

Selain sumber karbohidrat, Kabupaten Pati juga memiliki potensi yang tinggi dalam hal produksi sumber protein hewani khususnya ikan. Tahun 2015, produksi ikan laut sebanyak 52.793 ton. Ikan segar budidaya tambak seperti bandeng produksinya sebanyak 441.646 ton; udang windu sebanyak 63.170,6 ton; udang vaname sebanyak 27.260,6 ton. Sedangkan untuk budidaya di kolam seperti ikan lele produksinya sebanyak 8.272 ton (BPS Kabupaten Pati, 2016).
Potensi produksi pangan lokal yang ada di Kabupaten Pati seharusnya dapat mendukung perbaikan pola konsumsi pangan yang beragam, bergizi seimbang dan aman. Namun demikian, data menunjukkan pola konsumsi pangan masyarakat Kabupaten Pati belum ideal. Hal ini terlihat dari skor Pola Pangan Harapan (PPH) sebesar 85 (2014) dari skor ideal 100 (Gambar 1). Skor tersebut masih mencerminkan ketidakseimbangan pola konsumsi antara lain dicirikan masih tingginya konsumsi beras melebihi konsumsi yang dianjurkan yaitu sebesar 50\%. Tahun 2009 konsumsi beras masyarakat Kabupaten Pati melebihi 10,9\% dari anjuran. Tahun 2010 dan 2011 melebihi sekitar 9\% dari yang dianjurkan (Tabel 1). Selain itu, ketidakseimbangan pola konsumsi pangan juga terlihat dengan masih rendahnya konsumsi umbi-umbian, kelompok pangan hewani, buah dan sayuran.

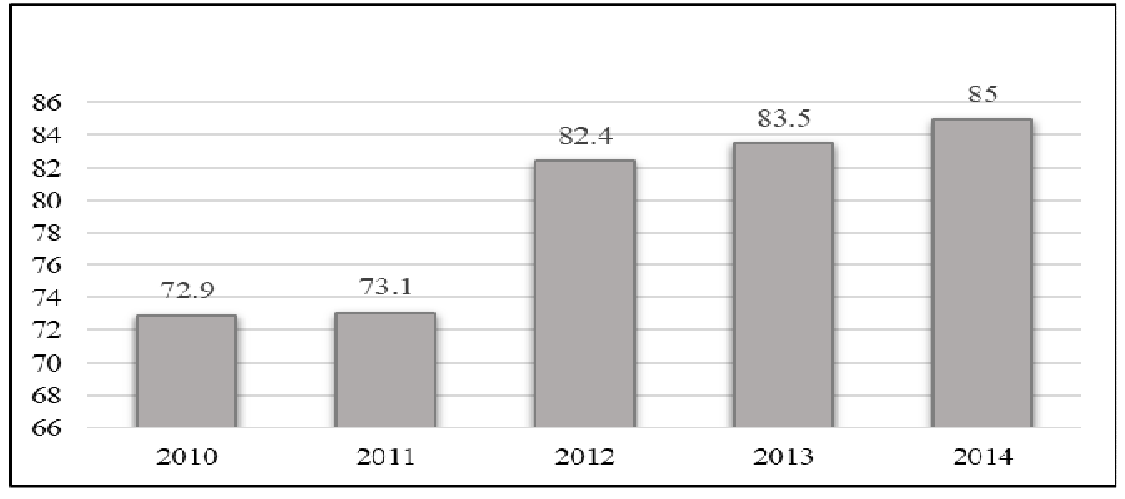

Gambar 1.

Skor PPH Kabupaten Pati Tahun 2010-2014

Sumber : Kantor Ketahanan Pangan Kab. Pati, 2016 (data diolah)

Tabel 1.

Konsumsi Energi Kelompok Padi-Padian (Beras) Kabupaten Pati Tahun 2009 s/d 2011

\begin{tabular}{cc}
\hline Tahun & \%AKE \\
\hline 2009 & 60,9 \\
2010 & 59,4 \\
2011 & 59,5 \\
\hline
\end{tabular}

Sumber : Kantor Ketahanan Pangan Kab. Pati, 2016 (data diolah) 
Pemerintah mengeluarkan kebijakan melalui Perpres Nomor 22 Tahun 2009 tentang Kebijakan Percepatan Penganekaragaman Konsumsi Pangan Berbasis Sumber Daya Lokal dan Peraturan Menteri Pertanian Nomor 43 tahun 2009 tentang Gerakan Percepatan Penganekaragaman Konsumsi Pangan Berbasis Sumber Daya Lokal. Tindak lanjut yang dilakukan Pemerintah Kabupaten Pati dalam mengupayakan penganekaragaman konsumsi pangan lokal melalui kebijakan yang diatur dalam Peraturan Bupati Pati Nomor 28 Tahun 2010 tentang Kebijakan Percepatan Penganekaragaman Konsumsi Pangan Berbasis Sumber Daya Lokal.

Tujuan penelitian ini adalah untuk mengetahui implementasi kebijakan diversifikasi konsumsi pangan lokal di Kabupaten Pati. Selain itu peneliti juga menganalisis faktor-faktor yang mempengaruhi implementasi kebijakan tersebut.

\section{TINJAUAN PUSTAKA}

\section{Kebijakan Publik}

Kebijakan publik muncul karena adanya masalah publik yang harus diselesaikan. Sesuatu dikatakan sebagai masalah publik jika melibatkan banyak orang dan mempunyai akibat tidak hanya pada orang-orang yang secara langsung terlibat, tetapi juga sekelompok orang lain yang secara tidak langsung terlibat (Winarno, 2008). Banyak ahli memberikan definisi tentang kebijakan publik. Salah satu diantaranya Thomas Dye dalam Nugroho (2008) mendefinisikan kebijakan publik sebagai segala sesuatu yang dikerjakan pemerintah, mengapa mereka melakukan, dan hasil yang membuat sebuah kehidupan bersama tampil berbeda.

Menurut Dunn (2003), kebijakan publik terbentuk melalui sebuah proses. Proses pembuatan kebijakan termasuk aktifitas politis yang digambarkan sebagai serangkaian tahap yang saling bergantung yang diatur menurut urutan waktu yaitu penyusunan agenda, formulasi kebijakan, adopsi kebijakan, implementasi kebijakan dan penilaian kebijakan. Tahapan-tahapan tersebut akhirnya terbentuk kebijakan publik.

\section{Diversifikasi Konsumsi Pangan Lokal}

Undang-Undang Nomor 18 tahun 2012 tentang Pangan mendefinisikan pangan lokal sebagai makanan yang dikonsumsi oleh masyarakat setempat sesuai dengan potensi dan kearifan lokal. Oleh karena itu, setiap wilayah memiliki jenis pangan lokal yang memiliki karakteristik yang berbeda yang disesuaikan dengan nilai-nilai sosial, selera dan budaya di wilayah tersebut. Pangan lokal merupakan bentuk kekayaan budaya kuliner Indonesia. Keanekaragamannya yang terbentuk atas dasar ketersediaan bahan baku dan kebutuhan lokal, menjadikannya memiliki tingkat kesesuaian yang tinggi dengan kebutuhan masyarakat akan energi bagi tubuhnya. Selain itu pemanfaatan berbagai pangan lokal akan berdampak baik bagi stabilitas pangan suatu daerah (Suismono \& Hidayah,2011).

Diversifikasi konsumsi pangan secara sederhana dapat dikatakan sebagai upaya peningkatan keanekaragaman konsumsi pangan ke arah yang sesuai prinsip atau kaidah gizi seimbang sehingga kualitas pangan menjadi semakin baik (Hardono, 2014). Tubuh manusia membutuhkan asupan makanan yang beragam karena tidak ada satu jenis makanan yang memiliki zat gizi yang lengkap. Manusia membutuhkan lebih dari 40 (empat puluh) jenis zat gizi yang terdapat pada berbagai jenis makanan untuk dapat hidup sehat, aktif dan produktif tubuh.

Diversifikasi konsumsi pangan dapat diukur dengan skor Pola Pangan Harapan (PPH). Skor PPH dihitung berdasarkan sembilan kelompok pangan, yaitu padi-padian, umbi-umbian, pangan hewani, minyak dan 
lemak, buah/biji berminyak, aneka kacang, gula, sayur dan buah, dan lain-lain. Semakin tinggi skor PPH menunjukkan bahwa pola konsumsi pangan semakin beragam, bergizi, dan seimbang. Skor maksimal PPH yaitu 100, artinya semakin mendekati angka 100 maka pola konsumsi telah terdiversifikasi dengan baik. Skor PPH nasional menunjukkan bahwa pola konsumsi pangan masyarakat masih belum ideal dan belum terdiversifikasi dengan baik. Hal ini terlihat dengan Skor PPH yang fluktuatif cenderung menurun pada tahun 2009 sampai dengan 2013 yaitu 75,7; 85,7; 85,60; 83,50; 781,40 (Badan Ketahanan Pangan Kementerian Pertanian, 2014). Data menunjukkan bahwa pola konsumsi masih didominasi oleh kelompok pangan padi-padian (beras), sedangkan kelompok umbi-umbian, pangan hewani, sayur dan buah-buahan masih jauh dari ideal.

Terkait dengan pangan lokal, skor PPH yang relatif masih rendah bukan berarti masyarakat tidak mengonsumsi pangan lokal. Mereka sudah mengonsumsi tetapi masih dalam porsi relatif sedikit dan tidak rutin, sehingga belum mampu mensubstitusi konsumsi pangan pokok utamanya, yaitu beras. Pangan lokal sumber karbohidrat, seperti ubi kayu dan jagung, lebih banyak disajikan dalam bentuk kudapan atau pangan selingan (Handono, 2014). Masyarakat akan mengalihkan konsumsi beras ke pangan lokal ketika harga beras naik dan kurang terjangkau. Namun demikian, mereka akan kembali mengkonsumsi beras sebagai pangan pokok saat harga beras terjangkau.

Pola diversifikasi konsumsi pangan di tingkat rumah tangga berbeda-beda antar wilayah. Menurut Hardono (2014) diversifikasi konsumsi pangan dipengaruhi oleh preferensi konsumsi anggota rumah tangga, faktor pendapatan, ketersediaan pangan alternatif, pengetahuan tentang pangan yang sehat dan berkualitas, dan faktor budaya. Selain itu diversifikasi pangan juga dipengaruhi oleh faktor pendidikan ibu rumah tangga.

Menurut Handono (2014), terdapat faktor yang mendorong diversifikasi antara lain: (1) potensi lahan subur masih banyak; (2) masih tersedia lahan kering dan marginal; (3) produksi pangan lokal meningkat; (4) harga pangan cenderung meningkat; (5) ragam jenis pangan lokal banyak; dan (6) adanya ragam pengolahan pangan lokal spesifik wilayah.

Menurut Handono (2014), beberapa hambatan terkait dengan diversifikasi pangan antara lain: (1) konversi lahan sawah subur relatif tinggi; (2) infrastruktur pertanian dan pendukung terbatas; (3) peran Pulau Jawa sebagai produsen pangan lokal berkurang; (4) kenaikan harga pangan tidak memberi insentif produksi bagi petani; (5) teknologi pengolahan pangan lokal terbatas; (6) preferensi pangan lokal terbatas; (7) penerapan kebijakan pengembangan konsumsi pangan lokal lemah; (8) kebijakan pengembangan produksi dan industri pangan lokal masih lemah; (9) penguasaan keterampilan penerapan teknologi pengolahan pada industri rumah tangga masih rendah; (10) adanya persepsi inferior terhadap pangan lokal di sebagian masyarakat; (11) belum berkembangnya pasar pangan lokal secara nasional; (12) budidaya sagu dan umbi lainnya belum berkembang; (13) Otonomi daerah (OTDA) tidak menciptakan kreasi pengembangan kebijakan pangan lokal; dan (14) promosi pangan lokal masih terbatas.

\section{Implementasi Kebijakan Publik}

Implementasi merupakan satu tahap bagian dari sebuah kebijakan. Implementasi kebijakan diperlukan karena pada tahap itulah dapat dilihat "kesesuaian" berbagai faktor determinan keberhasilan implementasi kebijakan atau program (Akib, 2010). Tahap implementasi menjadi tahap yang sulit karena 
pada tahap ini akan ditemui berbagai masalah yang ada di lapangan yang tidak dipikirkan dan tercakup dalam kebijakan yang telah dibuat. Selain itu, implementasi juga merupakan kegiatan yang kompleks karena melibatkan banyak aktor yang masing-masing memiliki kepentingan sendiri-sendiri

Peneliti menggunakan teori implementasi yang dikemukanan oleh Ripley. Ripley (1985) berpendapat bahwa implementasi dapat dilihat dari dua perspektif. Pertama memahami keberhasilan implementasi dalam arti sempit yaitu sebagai kepatuhan para implementer dalam melaksanakan kebijakan yang tertuang dalam dokumen kebijakan (Undang-undang, peraturan pemerintah dan program). Perspektif ini untuk mengetahui kepatuhan para bawahan dalam menjalankan perintah yang diberikan oleh para atasan melaksanakan sebuah kebijakan. Perspektif kepatuhan banyak dipengaruhi oleh pandangan yang melihat keberhasilan implementasi ditentukan oleh persoalan pengelolaan urusan administrasi dan manajemen. Keberhasilan implementasi dapat dilihat melalui serangkaian checklist tentang apa yang dilakukan implementer dalam menyampaikan berbagai policy output kepada kelompok sasaran (Purwanto \& Sulistyastuti, 2012).

Perspektif kedua memahami implementasi secara lebih luas yaitu mengukur keberhasilan implementasi dalam merealisasikan tujuan-tujuan kebijakan yang wujud nyatanya berupa munculnya dampak kebijakan. Kepatuhan para implementer dalam melaksanakan kebijakan dipandang sebagai kondisi yang harus dilalui, bukan tujuan akhir dari implementasi. Pencapaian tujuan kebijakan tidak hanya dengan mengikuti SOP saja tetapi dipengaruhi faktor seperti kecukupan keluaran kebijakan, kualitas keluaran kebijakan dan lain-lain (Purwanto \& Sulistyastuti, 2012).
Keberhasilan implementasi dapat dilihat dari kinerja (Lindquist \& Wanna, 2015). Alat bantu/indikator digunakan untuk menilai baik atau buruknya kinerja implementasi kebijakan. Indikator tersebut menjadi semacam penanda (milestone) yaitu menjadi penunjuk arah bahwa setahap demi setahap hasil implementasi kebijakan yang dilakukan menunjukkan tanda-tanda terwujudnya pencapaian tujuan kebijakan. Selain itu, indikator juga menjadi peringatan dini (early warning) apabila sesuatu yang salah dalam upaya pencapaian tujuan kebijakan sehingga pelaksana kebijakan akan memiliki cukup waktu untuk melakukan perbaikan implementasi kebijakan sebelum masalah sesungguhnya muncul. Indikator utama untuk mengukur kinerja dibedakan menjadi dua, yaitu: indikator output dan indikator outcome (Purwanto \& Sulistyastuti, 2012).

Indikator output digunakan untuk mengetahui konsekuensi langsung yang dirasakan oleh kelompok sasaran sebagai akibat adanya realisasi kegiatan, aktifitas, pendistribusian hibah, subsidi, dan lain-lain yang dilaksanakan dalam implementasi suatu kebijakan. Secara umum, apabila kebijakan yang ingin dievaluasi merupakan kebijakan distributif, maka indikator yang dapat digunakan untuk menilai output diantaranya: indikator akses, cakupan, frekuensi, bias dan akuntabilitas (Purwanto \& Sulistyastuti, 2012).

\begin{abstract}
Akses
Indikator akses digunakan untuk mengetahui bahwa program atau pelayanan yang diberikan mudah dijangkau oleh kelompok sasaran. Selain itu akses juga berarti bahwa orang-orang yang bertanggung jawab mengimplementasikan kebijakan mudah dihubungi masyarakat yang menjadi kelompok sasaran kebijakan/program jika mereka mem-
\end{abstract}


butuhkan informasi dan bantuan. Akses juga berarti tidak terjadi diskriminasi atau adanya kesamaan kesempatan bagi semua kelompok sasaran, apapun karakteristik individual maupun kelompok yang melekat pada dirinya, seperti: gender, etnisitas, agama \&afiliasi politik.

\section{Cakupan}

Indikator ini digunakan untuk menilai seberapa besar kelompok sasaran yang sudah dapat dijangkau yang mendapatkan layanan, bantuan oleh kebijakan publik yang telah diimplementasikan. Cakupan dapat diukur dengan cara: (1) Menetapkan data kelompok sasaran. Evaluator hendaknya memiliki data seluruh kelompok sasaran yang berhak menjadi penerima layanan; kemudian (2) Membuat proporsi jumlah kelompok sasaran yang sudah mendapatkan layanan dibanding total kelompok target.

\section{Frekuensi}

Indikator ini digunakan untuk mengukur seberapa sering kelompok sasaran memperoleh layanan sesuai dengan yang dijanjikan dalam kebijakan/ program tersebut. Indikator ini sesuai untuk mengukur implementasi kebijakan yang dilakukan berulang kali. Semakin tinggi frekuensi layanan yang diterima kelompok sasaran maka semakin baik implementasi kebijakan tersebut.

\section{Bias}

Indikator ini digunakan untuk menilai apakah pelayanan yang diberikan oleh pelaksana kebijakan bias atau menyimpang kepada kelompok masyarakat yang bukan menjadi sasaran atau kelompok masyarakat yang tidak berhak menerima layanan atau bantuan melalui kebijakan atau program.

\section{Akuntabilitas}

Indikator ini digunakan untuk menilai apakah tindakan para pelaksana kebijakan untuk menyampaikan keluaran kebijakan kepada kelompok sasaran dapat dipertanggungjawabkan atau tidak. Apa yang menjadi hak kelompok sasaran apakah sudah disampaikan semua atau ada yang dikurangi oleh pelaksana kebijakan, harus dapat dipertanggungjawabkan oleh pelaksana kebijakan.

\section{Kesesuaian Kebijakan dengan Kebutuhan}

Indikator ini digunakan untuk mengukur apakah berbagai keluaran kebijakan yang diterima oleh masyarakat sesuai dengan kebutuhan mereka atau tidak. Kebijakan yang dikeluarkan harusnya memberikan solusi atas permasalahan dan memenuhi kebutuhan yang dihadapi masyarakat. Sehingga dalam perumusan kebijakan yang diutamakan adalah untuk memenuhi kebutuhan masyarakat, bukan memenuhi kebutuhan pejabat atau pelaksana kebijakan. Proses perumusan kebijakan juga melibatkan masyarakat yang akan disasar sehingga keluaran kebijakan menjadi tepat guna dan tepat sasaran. Proses ini merupakan upaya untuk menjamin kesesuaian kebijakan dengan kebutuhan masyarakat.

Indikator untuk mengukur kinerja yang kedua yaitu indikator policy outcome. Indikator ini juga sering disebut dengan indikator dampak kebijakan (policy impact). Dampak kebijakan dapat dilihat dengan adanya perubahan kondisi masyarakat yang semula tidak baik/tidak diinginkan menjadi kondisi yang lebih baik atau yang dikehendaki. Perubahan yang terjadi tersebut perlu diukur agar mengetahui sejauh mana kinerja implementasi kebijakan atau program. Indikator policy outcome dibagi menjadi tiga berdasarkan waktunya, yaitu: (1) initial outcome atau hasil awal dari keluaran kebijakan; (2) intermediate outcome atau hasil jangka menengah dan (3) long term outcome atau hasil jangka panjang. 


\section{Faktor-Faktor yang Mempengaruhi Implementasi}

Pendekatan yang dipakai untuk menjelaskan fenomena implementasi kebijakan menggunakan pendekatan positivistic dimana setiap kejadian (akibat) pasti ada faktor-faktor yang dapat diidentifikasi sebagai penyebabnya. Begitupun keberhasilan atau kegagalan implementasi kebijakan dapat ditelusuri faktor-faktor penyebab keberhasilan kegagalannya (Purwanto \& Sulistyastuti, 2012).

Terkait perkembangan studi implementasi kebijakan, banyak ahli yang menyampaikan teori tentang variabel yang terlibat dalam implementasi antara lain Van Meter dan Van Horn (1975), George C. Edward III (1980), Daniel A. Mazmanian dan Paul A. Sabatier (1983), Goggin et.al (1990). Pada penelitian ini peneliti memilih teori yang dikemukakan oleh George C. Edwards III yang terdiri dari faktor: komunikasi, ketersediaan sumber daya, struktur birokrasi.

Selain tiga variabel tersebut, peneliti menambahkan satu variabel yang menurut peneliti memberikan pengaruh besar terhadap implementasi kebijakan diversifikasi konsumsi pangan lokal di Kabupaten Pati, yaitu sikap masyarakat terhadap pangan lokal. Berikut penjelasan masing-masing variabel:

\section{Komunikasi}

Komunikasi diartikan sebagai proses penyampaian informasi komunikator kepada komunikan. Komunikasi kebijakan berarti merupakan proses penyampaian informasi kebijakan dari pembuat kebijakan (policy maker) kepada pelaksana kebijakan (policy implementors) (Widodo, 2007)

Menurut George C. Edward III dalam Widodo (2007) komunikasi kebijakan memiliki tiga dimensi, antara lain; (1) transformasi (transmission) artinya kebijakan publik harus ditransformasikan kepada para pelaksana, kelompok sasaran, dan pihak lain yang terkait dengan kebijakan; (2) kejelasan (clarity) artinya kebijakan yang ditransmisikan kepada para pelaksana, kelompok sasaran, dan pihak lain yang berkepentingan langsung maupun tidak langsung terhadap kebijakan dapat diterima dengan jelas sehingga di antara mereka mengetahui apa yang menjadi maksud, tujuan dan sasaran serta subtansi dari kebijakan publik tersebut; (3) konsistensi (consistency) artinya implementasi kebijakan akan berjalan dengan efektif jika perintah-perintah pelaksanaan konsisten dan jelas.

\section{Sumber daya}

Meskipun kebijakan telah disampaikan dengan jelas kepada para pelaksana, implementasi kebijakan tidak akan berjalan efektif jika tidak didukung adanya sumber daya yang memadai. Sumber daya yang dibutuhkan meliputi sumber daya manusia, sumber daya keuangan, sumber daya peralatan (fasilitas), dan sumber daya informasi dan kewenangan.

Sumber daya manusia merupakan variabel yang mempengaruhi keberhasilan atau kegagalan implementasi kebijakan. Sumber daya yang dimaksud harus cukup dalam segi jumlah dan cakap/memiliki keahlian. Hal ini sesuai dengan pendapat Qian dalam Wang dan Wei (2009) yang mengatakan bahwa pelaksana kebijakan merupakan faktor utama yang mempengaruhi keberhasilan implementasi kebijakan.

Sumber daya kedua yang diperlukan untuk mendukung efektifitas implementasi kebijakan yaitu sumber daya keuangan. Sumber daya anggaran mempengaruhi implementasi kebijakan, jika anggaran terbatas maka pelayanan yang diberikan oleh aparat kepada masyarakat juga terbatas. Sumber daya 
keuangan yang terbatas akan mempengaruhi keberhasilan implementasi kebijakan. Disamping program tidak berjalan dengan baik, terbatasnya anggaran menyebabkan disposisi para pelaku kebijakan rendah (Widodo, 2007).

Sumber daya ketiga yang mendukung keberhasilan implementasi kebijakan yaitu sumber daya peralatan (fasilitas). Sumber daya peralatan merupakan sarana yang digunakan untuk operasionalisasi implementasi kebijakan yang meliputi gedung, tanah, dan sarana yang semuanya akan memudahkan dalam memberikan pelayanan dalam implementtasi kebijakan. Terbatasnya fasilitas menyebabkan kegagalan implementasi kebijakan terutama untuk teknologi informasi yang menyebabkan kesulitan mendapatkan informasi yang akurat, tepat, andal dan dapat dipercaya sehingga merugikan pelaksanaan akuntabilitas (Edward III dalam Widodo, 2007).

Sumber daya terakhir yang dibutuhkan untuk mendukung keberhasilan implementasi kebijakan yaitu sumber daya informasi dan kewenangan. Informasi yang relevan merupakan faktor penting dalam implementasi kebijakan terutama informasi yang berkaitan dengan bagaimana cara mengimplementasikan kebijakan. Selain informasi, kewenangan juga sangat diperlukan untuk menjamin dan meyakinkan bahwa kebijakan yang dilaksanakan sesuai dengan yang mereka kehendaki. Edward III dalam Widodo (2007) mengemukakan bahwa kewenangan yang cukup untuk membuat keputusan sendiri oleh suatu lembaga akan mempengaruhi lembaga tersebut dalam melaksanakan kebijakan.

\section{Struktur Birokrasi}

Menurut Edward III dalam Widodo (2007) implementasi kebijakan belum efektif karena adanya struktur birokrasi yang tidak efisien mencakup beberapa aspek yaitu struktur organisasi, pembagian kewenangan, hubungan antar unit-unit organisasi, pembagian wewenang, hubungan antara unit-unit organisasi dan hubungan organisasi dengan organisasi luar.

Struktur birokrasi mencakup dimensi fragmentasi dan dimensi Standard Operating Procedure (SOP). Dimensi fragmentasi menegaskan bahwa birokrasi yang terfragmentasi dapat menyebabkan kegagalan komunikasi. Organisasi pelaksana yang terfragmentasi (terpecah-pecah) akan menjadi distorsi dalam pelaksanaan kebijakan (Widodo, 2007). Semakin terpecah-pecah birokrasi maka semakin sulit untuk melakukan komunikasi dan koordinasi sehingga dapat menyebabkan kegagalan implementasi kebijakan.

Dimensi Standard Operating Procedure (SOP) terkait dengan mekanisme, sistem dan prosedur pelaksanaan kebijakan. Tidak jelasnya SOP termasuk pembagian tugas pokok, fungsi, kewenangan, dan tanggung jawab di antara pelaku ikut menentukan gagalnya pelaksanaan kebijakan (Widodo, 2007).

\section{Sikap Masyarakat Terhadap Pangan Lokal}

Menurut Sears dkk dalam Hidayah (2011) sikap diartikan sebagai keadaan mental dari kesiapan, yang diatur melalui pengalaman yang memberikan pe-ngaruh dinamik atau terarah terhadap respon individu pada semua objek dan situasi yang berkaitan dengannya. Berdasarkan tinjauan psikologis perilaku makan, ada beberapa atribut personal yang mempengaruhi individu dalam memilih bahan pangan. Faktor tersebut antara lain persepsi terhadap atribut sensorik (cita rasa dan tekstur), faktor psikologi (faktor emosi dan faktor sikap) lingkungan sosial (norma budaya, pengiklanan), faktor ekonomi, dan faktor ketersediaan produk makanan. 
Sikap masyarakat terhadap pangan lokal mempengaruhi implementasi kebijakan diversifikasi konsumsi pangan lokal. Semakin baik dukungan dan penerimaan masyarakat terhadap pangan lokal maka diversifikasi konsumsi pangan berbasis sumber daya lokal akan terwujud dengan baik, dan begitupun sebaliknya.

\section{METODE PENELITIAN}

Penelitian ini menggunakan metode kualitatif. Pengumpulan data dilakukan melalui tiga cara yaitu observasi, wawancara dan dokumentasi. Penelitian dilakukan di Kabupaten Pati, dengan melakukan wawancara mendalam kepada 18 (delapan belas) informan yang berasal dari instansi yang melaksanakan kebijakan diversifikasi konsumsi pangan lokal, dan kelompok sasaran/ masyarakat yang menerima layanan kebijakan. Informan terdiri dari 7 orang yang berasal dari instansi pemerintah daerah Kabupaten Pati dan 11 orang dari kelompok sasaran/masyarakat. Informan dari instansi yaitu Kepala Kantor Ketahanan Pangan Kabupaten Pati, Kepala Seksi Konsumsi dan Keamanan Pangan, Bagian Program Dinas Pertanian, Tanaman Pangan dan Peternakan Kabupaten Pati, Kepala Bidang Pengelolaan dan Pengembangan Produk Kelautan dan Perikanan Dinas Kelautan dan Perikanan, Kepala Bidang Perdagangan Dinas Perindustrian dan Perdagangan, Kepala Seksi Kesehatan Lingkungan Dinas Kesehatan dan Penyuluh Pertanian. Informan dari kelompok sasaran/masyarakat yaitu Ketua Pokja III TP PKK Kab. Pati, Kepala SD Kutoharjo 3, Ketua Kelompok Wanita Tani berjumlah 7 orang, Ketua Pondok Pesantren Darur Ridhwan dan pemilik katering Rahajeng. Penetapan informan dalam penelitian ini telah dipilih dengan pertimbangan bahwa informan memiliki pengetahuan yang cukup banyak tentang pelaksanaan kebijakan diversifikasi konsumsi pangan lokal di Kabupaten Pati.

Analisis data yaitu; (1) Reduksi data. Mereduksi data berarti merangkum, memilih hal-hal yang pokok, memfokuskan pada halhal yang penting, dicari tema dan polanya. Peneliti melakukan reduksi data dengan memilih jawaban dan informasi yang sesuai dengan tujuan penelitian dan menghilangkan jawaban dan informasi yang tidak sesuai; (2) Penyajian data. Data disajikan dalam bentuk teks yang bersifat naratif, gambar, tabel dan grafik. Penyajian data ini akan memudahkan untuk memahami apa yang terjadi, merencanakan kerja selanjutnya berdasarkan apa yang terlah dipahami tersebut. (3) Penarikan kesimpulan. Kesimpulan awal yang dikemukakan masih bersifat sementara, dan akan berubah jika tidak ditemukan bukti-bukti yang kuat yang mendukung pada tahap pengumpulan data berikutnya. Kesimpulan ini merupakan temuan baru yang belum pernah ada.

\section{HASIL DAN PEMBAHASAN}

\section{Implementasi Kebijakan Diversifikasi Konsumsi Pangan Lokal}

\section{a. Kepatuhan Implementer Melaksanakan Kebijakan}

Keberhasilan sebuah kebijakan sangat dipengaruhi oleh implementing agency yaitu keberadaan organisasi atau lembaga yang diberi mandat untuk mengimplementasikan suatu kebijakan. Peran implementing agency sangat vital sebab lembaga inilah yang akan menjamin kegiatan penyampaian kebijakan berjalan dengan lancar. Tujuan-tujuan kebijakan yang telah dirancang sebelumnya tidak akan dapat tercapai tanpa mekanisme penyampaian yang baik maka (Purwanto \& Sulistyastuti, 2012).

Berdasarkan hasil penelitian, pelaksana kebijakan tidak sepenuhnya mematuhi apa 
yang telah diatur dalam Perbup Pati Noor 28 tahun 2010. Sosialisasi kebijakan tidak dijalankan dengan baik sehingga instansi yang terlibat tidak semuanya mengetahui kebijakan tersebut dengan jelas. Pelaksanaan kebijakan lebih banyak dilakukan di Kantor Ketahanan Pangan. Pelaksana kebijakan dalam Perbup tercantum 11 (sebelas) instansi di Kabupaten Pati, namun hanya 7 (tujuh) instansi yang aktif terlibat dalam pelaksanaan kebijakan yaitu Kantor Ketahanan Pangan, Dinas Kesehatan, Dinas Pertanian Tanaman Pangan dan Peternakan, Dinas Kelautan dan Perikanan, Dinas Pendidikan, Dinas Perindustrian dan Perdagangan, dan Tim Penggerak PKK Kabupaten Pati.

Minimnya keterlibatan para pelaksana kebijakan juga disebabkan karena Koordinator pelaksana kebijakan yaitu Sekretaris Daerah kurang memberikan perhatian dalam pelaksanaan kebijakan tersebut. Sedangkan posisi Kantor Ketahanan Pangan yang status eselonnya lebih rendah dari pada instansi yang lain yang terlibat mengalami kesulitan untuk melakukan koordinasi dengan instansi lain.

Pelaksanaan kegiatan operasional sebagaimana tercantum dalam Perbup Nomor 28 Tahun 2010 dibagi dalam dua tahap yaitu Tahap I (2009-2011) dan Tahap II (20122015). Berdasarkan hasil penelitian, pelaksanaan kegiatan operasional tahap I tidak dilakukan tepat waktu. Tahap I baru mulai dilaksanakan pada tahun 2011. Keterlambatan pelaksanaan kegiatan operasional Tahap I berdampak tidak terlaksananya kegiatan operasional tahap II. Selain itu, pelaksana juga tidak melakukan evaluasi kebijakan sehingga tidak diketahui hasil kinerja pelaksanaan kebijakan.

\section{b. Kualitas Keluaran Kebijakan}

Untuk mengukur kualitas keluaran digunakan indikator output policy dan outcome policy. Indikator output policy terdiri dari beberapa sub indikator yaitu: (1) Akses, Hasil penelitian menunjukkan bahwa pelayanan yang diberikan kepada masyarakat/kelompok sasaran mudah dijangkau atau diakses oleh kelompok sasaran baik secara langsung maupun lewat media komunikasi seperti telepon.

(2) Cakupan, Indikator ini digunakan untuk menilai seberapa besar kelompok sasaran yang sudah dapat dijangkau oleh kebijakan diversifikasi konsumsi pangan lokal di Kabupaten Pati. Perbup Pati Nomor 22 Tahun 2010 tidak mengatur dengan jelas siapa kelompok sasaran kebijakan. Menurut informasi dari Kasi Konsumsi dan Keamanan Kantor Ketahanan Pangan, sasaran kebijakan ini adalah masyarakat di Kabupaten Pati. Penyaluran layanan dipermudah dengan dibuat semacam kelompok-kelompok yang disesuaikan dengan program/kegiatan yang dilaksanakan. Kegiatan kampanye, sosialisasi dan promosi yang dilakukan belum dapat menjangkau ke seluruh masyarakat Kabupaten Pati. Kegiatan promosi yang dilakukan setiap bulan sekali pada acara car free day dan event lainnya, hanya dapat dinikmati oleh orangorang yang saat itu berada di lokasi tersebut.

Pembinaan mutu dan keamanan pangan hanya dilakukan kepada industri rumah tangga dan UMKM di bidang pangan yang mengajukan permohonan PIRT saja sehingga industri rumah tangga dan UMKM dibidang pangan yang belum mengajukan permohonan PIRT belum mendapatkan pembinaan. Hal itu dilakukan karena keterbatasan jumlah tenaga penyuluh yang dimiliki sampai saat ini.

(3) Frekuensi, layanan yang diberikan seperti pemberian makanan tambahan Beragam Bergizi Seimbang dan Aman (B2SA) kepada murid-murid di SD hanya dilakukan satu kali saja per SD. Padahal idealnya pemberian makanan tambahan akan lebih 
efektif jika diberikan secara berkala seperti satu bulan sekali atau tiga bulan sekali. Kegiatan pembinaan mutu dan keamanan pangan seperti pemberian penyuluhan dan pengawasan kepada industri rumah tangga dan UMKM di bidang pangan tidak dilakukan secara berulang-ulang. Menurut hasil wawancara dengan informan, pengawasan yang dilakukan kepada industri rumah tangga dan UMKM di bidang pangan yang sudah mendapatkan PIRT hanya dilakukan secara insidental dan hanya dilakukan secara acak dengan mengambil 1 sampel di setiap kecamatan.

(4) Bias, pembinaan mutu dan keamanan pangan seharusnya diberikan kepada seluruh industri rumah tanggga dan UMKM di bidang pangan yang ada di Kabupaten Pati. Namun demikian, dalam pelaksanaannya hanya dilakukan kepada industri rumah tanggga dan UMKM di bidang pangan yang mengajukan permohonan PIRT saja. Selain itu, dalam penelitian ini juga menemukan adanya ketidaksesuaian kelompok sasaran penerima layanan yang berasal dari usulan anggota DPRD yang kualifikasinya kurang memenuhi persyaratan.

(5) Akuntabilitas, Pelaksana kebijakan dalam memberikan layanan khususnya hibah (barang dan uang) tidak melakukan pemotongan dana sama sekali. Penyaluran hibah uang dilakukan dengan mentransfer langsung ke rekening kelompok.

(6) Kesesuaian program/kebijakan dengan kebutuhan, Berdasarkan hasil wawancara dengan kelompok sasaran yang mendapatkan layanan mengatakan bahwa kebijakan ini memberikan manfaat dan sesuai dengan kebutuhan mereka. Namun untuk kelompok penerima bantuan MP3L (Model Pengembangan Pangan Pokok Lokal) menganggap bahwa program tersebut tidak menjawab kebutuhan masyarakat. Meskipun sudah berhasil membuat beras analog yang bisa dijadikan subtitusi beras nasi, beras analog tersebut tidak dapat diterima masyarakat karena harganya yang jauh lebih mahal dibandingkan dengan harga beras biasa. Akibatnya, tujuan program untuk mengembangkan pangan lokal sumber karbohidrat non beras non terigu dengan cara membuat beras analog sebagai pengganti beras tidak tercapai.

Indikator Policy Outcome terdiri dari initial outcome, intermediate outcome dan long term outcome. Initial outcome kebijakan ini terdiri dari dua hal yaitu: (1) aneka ragam makanan berbasis sumber daya lokal makin banyak tersedia di masyarakat, memiliki citra yang baik, rasa enak dan harga kompetitif. Indikator ini tercapai dimana terlihat dengan adanya berbagai jenis aneka olahan makanan berbahan lokal dan makanan segar lokal yang dipasarkan di pasar unggulan; (2) Teknologi kuliner dan bisnis bidang makanan berskala mikro kecil dan menengah berdasarkan kearifan dan budaya lokal semakin berkembang. Berdasarkan pengamatan peneliti, pela$\mathrm{ku}$ bisnis bidang makanan sudah mulai menggunakan teknologi untuk mengembangkan usaha meskipun teknologi yang dipakai masih tergolong sederhana. Teknologi yang lazim dipakai antara lain: spinner, sealer, mesin vakum.

Indikator intermediate outcome yaitu meningkatnya peran swasta dan pemerintah dalam memanfaatkan keragaman sumber daya lokal. Jika dilihat dari sisi pemerintah, perannya sudah baik dalam memanfaatkan keragaman sumber daya lokal. Hal ini dapat dilihat dari penggunaan pangan lokal sebagai suguhan dalam kegiatan rapat atau pertemuan di instansi pemerintah Kabupaten Pati. Sedangkan dari sisi swasta, perannya dalam memanfaatkan sumber daya lokal masih kurang. Hal tersebut terutama terlihat dari penggunaan tepung mocaf yang masih minim dalam usaha jasa boga. 
Indikator long term outcome yaitu menu makanan sehari-hari makin beragam, bergizi, seimbang dan aman. Kualitas dan keragaman konsumsi pangan dapat dilihat dengan mengetahui capaian skor Pola Pangan Harapan $(\mathrm{PPH})$. Skor PPH tertinggi yaitu 100 yang menggambarkan bahwa penganekaragaman konsumsi pangan sudah sempurna. Jika dilihat dari data Skor PPH Kabupaten Pati dari tahun 2009 sampai dengan 2015 terlihat bahwa skor yang dicapai mengalami fluktuasi. Tahun 2009 sampai dengan 2011, konsumsi padi-padian melebihi standar sedangkan konsumsi umbiumbian masih jauh dari angka ideal. Konsumsi padi-padian mulai mengalami penurunan sejak tahun 2012 sampai dengan tahun 2015, namun justru penurunannya sampai di bawah angka ideal. Selain itu penurunan konsumsi beras juga tidak diimbangi dengan kenaikan konsumsi umbi-umbian yang signifikan. Jika dikaitkan dengan hasil temuan penelitian yang dilakukan oleh Purwantini \& Susilowati (2014) konsumsi pangan sumber karbohidrat masyarakat beralih ke pangan berbasis terigu seperti mie instan atau roti.

\section{Faktor-Faktor yang Mempengaruhi Implementasi Kebijakan Diversifikasi Konsumsi Pangan Lokal}

Faktor-faktor yang mempengaruhi implementasi kebijakan diversifikasi konsumsi pangan lokal di Kabupaten Pati sebagai berikut:

\section{a. Komunikasi}

Komunikasi menjadi faktor penting dalam implementasi kebijakan. Widodo (2007) menyebutkan bahwa komunikasi kebijakan merupakan proses penyampaian informasi kebijakan dari pembuat kebijakan (policy maker) kepada pelaksana kebijakan (policy implementors). Berdasarkan hasil penelitian, proses penyampaian kebijakan dari pembuat kebijakan kepada pelaksana kebijakan tidak berjalan dengan baik. Sosialisasi kebijakan tidak dilakukan dengan baik sehingga pelaksana yang terlibat tidak mengetahui isi kebijakan tersebut. Hal ini terlihat dari hasil wawancara kepada instansi yang seharusnya terlibat dalam pelaksanaan kebijakan, mereka mengaku tidak mengetahui Perbup Nomor 28 tahun 2010. Hal ini berdampak pada minimnya keterlibatan instansi dalam pelaksanaan kebijakan tersebut.

\section{b. Sumber Daya}

Menurut Subarsono (2011), meskipun isi kebijakan sudah dikomunikasikan dengan jelas dan konsisten, namun apabila pelaksana kebijakan kekurangan sumber daya maka pelaksanaan kebijakan tidak berjalan efektif. Hasil penelitian menunjukkan bahwa pelaksanaan kebijakan diversifikasi konsumsi pangan lokal di Kabupaten Pati tidak berjalan efektif karena kekurangan sumber daya manusia. Jumlah pelaksana yang terlibat sebanyak 7 (tujuh) instansi dari 11 (sebelas) instansi di Kabupaten Pati yang seharusnya melaksanakan kebijakan tersebut. Instansi yang belum berperan yaitu Badan KB dan Pemberdayaan Perempuan, Badan Pemberdayaan Masyarakat dan Desa, Dinas Pemuda Kebudayaan Pariwisata Pemuda dan Olah Raga, dan Sekretariat Daerah Kabupaten Pati.

\section{c. Struktur Organisasi}

Salah satu aspek struktural paling dasar dari suatu organisasi adalah prosesur kerja ukuran dasar (Standard Operating Prosedurel SOP). SOP menyeragamkan tindakan-tindakan dari para pejabat dalam organisasi-organisasi yang kompleks dan tersebar luas, yang pada gilirannya dapat menimbulkan fleksibilitas besar dan kesamaan yang besar dalam penerapan peraturan-peraturan (Winarno, 2008). Berdasarkan hasil penelitian, Kantor Ketahanan Pangan selaku instansi pelaksana yang dominan dalam pelaksanaan kebijakan 
diversifikasi konsumsi pangan lokal baru menyusun SOP pada tahun 2014 dan efektif dilaksanakan pada tahun 2015. Tidak adanya SOP sejak awal pelaksanaan kebijakan menyebabkan adanya miss link antara pejabat baru yang menggantikan pejabat lama yang menangani kebijakan ini.

\section{d. Sikap Masyarakat Terhadap Pangan Lokal}

Berdasarkan hasil wawancara dengan informan, salah satu hambatan pelaksanaan kebijakan ini adalah mind set masyarakat tentang pangan lokal. Masyarakat ada yang menganggap pangan lokal sebagai makanan inferior atau kelas bawah. Ada anggapan bahwa makanan seperti ketela, jagung, talas dan lain-lain adalah makanan ndeso dan kuno. Akibatnya kecenderungan masyarakat lebih memilih mengkonsumsi roti atau makanan ala western food yang dianggap sebagai makanan yang lebih modern.

\section{KESIMPULAN DAN SARAN}

\section{Kesimpulan}

Kesimpulan penelitian yaitu: (1) aspek kepatuhan pelaksana dalam melaksanakan kebijakan, implementasi kebijakan diversifikasi konsumsi pangan lokal di Kabupaten Pati gagal atau tidak berjalan dengan baik; (2) Indikator policy output, implementasi kebijakan diversifikasi konsumsi pangan lokal di Kabupaten Pati hasilnya tidak efektif; (3) Indikator policy outcome, dari empat indikator keberhasilan kebijakan diversifikasi konsumsi pangan lokal hanya dua yang tercapai sedangkan yang lainnya tidak tercapai; (4) Faktor-faktor yang mempengaruhi kegagalan implementasi kebijakan diversifikasi konsumsi pangan di Kabupaten Pati adalah komunikasi, sumber daya, struktur organisasi, sikap masyarakat terhadap pangan lokal.

\section{Saran}

Saran untuk perbaikan; (1) Pemerintah sebaiknya memperhatikan pentingnya komunikasi terutama sosialisasi kepada para pelaksana kebijakan mengingat komunikasi menjadi faktor yang sangat berpengaruh terhadap implementasi kebijakan; (2) Perlu dibentuk tim teknis untuk memudahkan koordinasi antar para pelaksana kebijakan Tim Teknis diketuai Kepala Kantor Ketahanan Pangan yang menangani urusan ketahanan pangan di Kabupaten Pati; (3) Meningkatkan kampanye, promosi dan edukasi pangan lokal kepada masyarakat sehingga pola pikir tentang pangan lokal yang dianggap inferior bisa berubah.

\section{DAFTAR PUSTAKA}

Akib, H. (2010). Implementasi Kebijakan: Apa, Mengapa dan Bagaimana. Jurnal Administrasi Publik, 1 (1), 1-11.

Badan Ketahanan Pangan Kementerian Pertanian. (2013). Statistik Ketahanan Pangan Tahun 2013

Badan Pusat Statistik. (2016). Pati Dalam Angka Tahun 2015. Pati.

Dunn, W. (2003). Pengantar Analisis Kebijakan Publik (Samodra Wibawa dkk, penerjemah). Yogyakarta: Gadjah Mada University Press.

Hardono, G. S. (2014). Strategi Pengembangan Diversifikasi Pangan Lokal. Analisis Kebijakan Pertanian, 12(1), $1-17$

Hidayah, N. (2011). Kesiapan Psikologis Masyarakat Pedesaan dan Perkotaan Menghadapi Diversifikasi Pangan Pokok. Humanitas, VII (1), 88-104.

Kantor Ketahanan Pangan Kabupaten Pati. (2016). Konsumsi Energi Kelompok Padi-Padian (Beras) Kabupaten Pati 
Tahun 2009 s/d 2011. Pati: Kantor Ketahanan Pangan Kabupaten Pati.

Kantor Ketahanan Pangan Kabupaten Pati. (2016). Skor PPH Kabupaten Pati Tahun 2010-2014. Pati: Kantor Ketahanan Pangan Kabupaten Pati.

Lindquist, E., Wanna, J. (2015). Is Implementtion Only About Policy Execution?: Advice for Public Sector Lead,er from the Literature. Canberra : ANU Press

Nugroho, R. (2003). Kebijakan Publik Formulasi, Implementasi dan Evaluasi. Jakarta: Elex Media Komputindo. (2008). Public Policy. Jakarta : Elex Media Komputindo

Peraturan Bupati Pati Nomor 28 Tahun 2010 tentang Kebijakan Percepatan Penganekaragaman Konsumsi Pangan Berbasis Sumber Daya Lokal.

Peraturan Menteri Pertanian Republik Indonesia Nomor 43 tahun 2009 tentang Gerakan Percepatan Penganekaragaman Konsumsi Pangan (P2KP) Berbasis Sumber Daya Lokal.

Peraturan Presiden Republik Indonesia Nomor 22 Tahun 2009 tentang Kebijakan Percepatan Penganekaragaman Konsumsi Pangan Berbasis Sumber Daya Lokal.

Purwantini,T. B., Susilowati, S. H. (2014). Pergeseran Peran Pangan Berbahan Baku Lokal pada Pola Konsumsi Rumah Tangga di Indonesia. Prosiding Seminar Nasional Hari Pangan Sedunia Ke-3. Bogor: Pusat Sosial Ekonomi dan
Kebijakan Pertanian. Kementerian Pertanian 21-22 Oktober 2013.

Purwanto, E. A., Sulistyastuti, D. R. (2012). Implementasi Kebijakan Publik: Konsep dan Aplikasinya di Indonesia. Yogyakarta: Gava Media.

Ripley, R. B. (1985). Policy Analysis in Political Science. Chicago : Nelson Hall.

Subarsono, A. G. (2011). Analisis Kebijakan Publik: Konsep, Teori dan Aplikasi. Yogyakarta: Pustaka Pelajar.

Suismono, Hidayah, N. (2011). Pengembangan Diversifikasi Pangan Pokok Lokal. Jurnal PANGAN, 20(3), 295-314

Undang-Undang Nomor 18 tahun 2012 tentang Pangan

Wang, J. S \& Wei, F. (2009). Distortions in Implementing Public Policy. Transnational Corporations Revies, 1(4), 67-71

Wibawa, S. (2011). Politik Perumusan Kebijakan Publik. Yogyakarta: Graha Ilmu.

Wibawa, S., Purbokusumo, Y., Pramusinto, A. (1994). Evaluasi Kebijakan Publik. Jakarta: Raja Gravindo Persada.

Winarno, B. (2008). Kebijakan Publik :Teori \& Proses. Yogyakarta: Media Pressindo.

\section{BIODATA PENULIS}

Sri Utami, lahir 13 Mei 1986 di Kudus Jawa Tengah. Menyelesaikan pendidikan S1 dari jurusan Manajemen Universitas Diponegoro Semarang. Gelar Magister Administrasi Publik diperoleh dari Universitas Gadjah Mada. Saat ini bekerja di Dinas Ketahanan Pangan Kabupaten Pati. 